\title{
$\mathrm{RDF} / \mathrm{OWL}$ 의 객체속성을 이용한 관계온톨로지 시스템 구축과 활용에 관한 연구
}

\section{A Study on Implementation and Applying Relationship Ontology System Using RDF/OWL Object Property}

강현민(Hyen-Min Kang)**

\section{초 록}

FRBR, FRAD 개념모형과 RDA 목록규칙에는 서지개체와 접근제어개체 간 다양한 수준에서 발생하는 복합적이고 다원적인 관계유형들이 규정되어 있다. 본 연구에서는 이러한 관계유형을 술어논리에 기반하 여 온톨로지 환경에서 개체 클래스의 인스턴스와 인스턴스 간 관계를 RDF/OWL의 객체속성(Object Property)을 서지세계의 개체 간 관계기술과 접근을 위한 새로운 제어기제이자 통합적 연결장치로서 그 적용과 활용 가능성을 시도하였다. 이를 위해 관계온톨로지 시스템을 구축하고 SPARQL 질의결과를 온톨로지 시각화도구를 통해 제시하였다. 이로써 온톨로지 기반의 '관계기술목록'이라는 새로운 목록업무 영역의 확장을 통해, 목록기능의 '다 대 다 집중'이라는 의미 확장, '개체단위 기반의 의미적 집중', $\mathrm{RDF} / \mathrm{OWL}$ 객체속성의 계층관계 상속을 이용한 '관계 추론' 등을 연구결과로 제시하였다.

\section{ABSTRACT}

This study proposes a 'Bibliographic Universe Relationship Vocabulary'(burv) using the RDF/OWL Object Property under the SPO predicate logic according to the relationship type among all entities of bibliographic universe and implemented a relationship ontology system' to establish a new cataloging business domain called 'Relationship Description Cataloging' based on the ontology.

키워드: $\mathrm{RDF} / \mathrm{OWL}$, 객체속성, 관계기술목록, 관계온톨로지, 술어논리, SPARQL, 온톨로지 시각화 object property, relationship description catalog, relationship ontology, predicate logic

* 본 논문은 연세대학교 문헌정보학과 박사학위 논문(2010. 8)을 요약한 것임.

** 행정안전부 국가기록원(xianmin70@yahoo.co.kr, http://kr.blog.yahoo.com/xianmin70/)

- 논문접수일자 : 2010년 11월 15일 - 최초심사일자 : 2010년 11월 20일 - 게재확정일자 : 2010년 11월 25일

- 정보관리학회지, 27(4) : 219-237, 2010. [DOI:10.3743/KOSIM.2010.27.4.219] 


\section{1. 서 론}

최근 발표된 $\mathrm{FRBR}, \mathrm{FRAD}$ 개념모형과 RDA 목록규칙에는 다양한 서지개체와 접근제어개체 가 정의되었고 이들 간에 다양한 수준에서 발생 하는 복합적이고 다원적인 관계유형들이 규정 되어 있다. 이러한 최근의 목록환경의 변화는 전통적 목록에서 사용되었던 서지적 연결장치 (bibliographic linking devices)를 대치하고, 개체 간에 발생하는 다양하고 복잡한 관계가 존재하는 서지세계를 보다 정교하고 상세하게 서지 모델링하는 관계기술 기능과 복합적이고 다원적인 개체로의 접근기능, 즉 연결(link) 기 능을 모두 갖춘 새로운 메커니즘을 기반으로 작동하는 통합적인 연결장치가 필요하다는 것 을 의미한다.

본 연구에서는 온톨로지 환경에서 개체 클래 스의 인스턴스와 인스턴스 간 이항관계(binary relationship)를 의미적으로 '기술'하며 물리적 으로도 상호 '연결과 접근' 기능까지 수행하는 $\mathrm{RDF} / \mathrm{OWL}$ 의 객체속성(Object Property)을 서지세계의 개체 간 관계기술과 접근을 위한 새로운 제어기제이자 통합적 연결장치로서 그 적용과 활용 가능성을 시도하였다.

\section{2. $\mathrm{RDF} / \mathrm{OWL}$ 의 객체속성과 관계어휘}

\subsection{RDF/OWL의 객체속성}

2004년 W3C의 권고안이 된 OWL(Web Ontology Language) 은 웹 온톨로지 마크업 언어
로서 $\mathrm{RDF}$ 와 $\mathrm{RDFS}$ 의 문제점을 보완하고 개념 이나 자원의 관계를 정밀하게 나타내거나 추론 가능한 논리를 기술하기 위한 보다 세련된 어휘 이다. OWL은 RDFS의 클래스와 속성의 의미 를 그대로 수용하고 보다 풍부한 표현력을 지원 하는 근원적 언어를 추가했다는 점에서 $\mathrm{RDFS}$ 의 확장이라 할 수 있다(Grigoris Antoniou etc. 2008, 116).

한편 OWL의 객체속성(Object Property) 은 RDFS의 속성(Property)의 하위 클래스로 서 그 특징을 그대로 수용하면서, 개체 간의 관 계를 다양한 공리(axiom)를 통해 보다 세밀하 게 표현하는 것이 가능하다. 객체속성의 주요 특징은 첫째, 관계하는 주어 클래스인 정의역 과 목적어 클래스인 치역을 기술함으로써 객체 속성의 외연(extension)을 정의할 수 있다. 즉, 어떤 객체속성을 취할 수 있는 클래스의 범위 를 제한하고 그 객체속성이 취할 수 있는 인스 턴스의 범위를 제한할 수 있다. 둘째, 독립형 클 래스로 정의되며 객체속성 간 추이적 계층관계 를 통한 외연 상속이 가능하다. 셋째, 공리를 통 해 강화된 표현력을 갖는 객체속성의 정의가 가능하다. 즉, 1) 동치관계, 반대관계 등 다른 객체속성 간 관계표현, 2) 함수형, 역함수형 등 객체속성의 출현횟수에 대한 제약선언, 3) 추 이성, 대칭성 등 객체속성의 논리적 특질 등과 같은 객체속성 공리 정의가 가능하다.

특히 객체속성은 특정 클래스에 적용되고 있 는 객체속성에 대해 클래스 정의 변경 없이 새로 운 객체속성의 정의가 가능하다. 정의된 객체속 성, 즉 어휘는 기존의 어휘를 확장하거나 상세화 하여 새로운 어휘를 정의할 수도 있다는 것을 의 미한다. 어휘는 누구든지 정의할 수 있고, 또한 
누가 정의한 어휘라도 다시 이용할 수 있다. 개 별적으로 정의된 여러 개의 어휘들을 자유롭게 조합하여 자원을 기술할 수도 있으며, 새롭게 정 의한 독자적인 어휘를 다른 어휘와 관련시켜 의 미네트워크를 확장해 가는 것도 가능하다는 것 을 의미한다(Kanzaki Masahide 2005, 76).

이러한 객체속성의 특징을 이용하면 서지세 계의 개체를 클래스로 정의하고 이들 인스턴스 간의 관계를 객체속성으로 표현한 서지세계 관 계어휘(Bibliographic Universe Relationship Vocabulary, 이하 burv)를 설계할 수 있다. 또한 이러한 객체속성의 특징을 이용해 서지세계의 어 휘스키마인 burv 관계어휘를 구성하고, FRBR, $\mathrm{FRAD}$ 에서 제시하고 있는 개념모형과 관련해 클래스 간 인스턴스의 관계를 보다 세밀하게 표현하기 위해, 다양한 클래스공리와 객체속성 공리로 모델링한 burv 관계온톨로지를 구축할 수 있다.

\section{2 관계어휘}

관계어휘는 FRBR, FRAD, RDA에 정의되 어 있는 개체와 관계유형들을 조사하여 수집하 였다. FRBR은 IFLA 목록분과 상임위원회의 승인을 얻어 1997년 9월에 발표된 최종보고서 의 2009년 2월 수정 - 보완판을 대상으로 하였 다. FRAD는 IFLA의 FRANAR 실무그룹에 서 작성된 '전거데이터의 기능상의 요건: 개념 모형' 2007년 4월 최종보고서를 대상으로 하였 으며, RDA는 영미목록규칙합동개정위원회가 작성 중인 새로운 목록규칙인 '자원의 기술과 접근'의 2008년 10 월 31 일 초안판을 대상으로 하였다.
관계어휘는 관계유형의 범주별로 다음과 같 은 어휘군으로 구성하였다.

첫째, 서지관계어휘는 FRBR, FRAD, RDA 에서 제시된 11 종의 서지개체에 존재하는 관계 유형 중 각각 제 1 집단 내와 제 2 집단 내에서 발 생하는 관계유형을 중심으로 구성한 어휘군이 다. 제1집단은 저작, 표현형, 구현형, 개별자료 간 서지적 관계가 중심이고 제 2 집단은 인물, 단 체, 가족 간의 귀속관계, 필명관계, 합작관계, 구성원관계, 합병관계 등 새로운 관계유형들이 중심이다.

둘째, 역할관계어휘는 제1집단과 제 2 집단 간 의 개체들의 역할(role) 유형 즉 역할관계에 따 라 구성한 관계어휘군이다. 이 어휘는 인물, 단 체, 가족이 저작, 표현형, 구현형, 개별자료에 대 한 저자성을 밝히는 구체적인 어휘이다. FRBR 에서는 '책임관계'라고도 하며, 제2집단 인물, 단체는 저작에 대해 '창작하다', 표현형에 대해 '실현하다', 구현형에 대해 '제작하다', 개별자료 에 대해 '소장하다'라는 책임관계로서의 역할 (role)이 정의되어 있다. FRAD모형에서는 단 지 제 1 집단과 제 2 집단 간 관계를 일반적 수준 에서 ' 관련되다'라고만 정의하고 있다. $\mathrm{RDA}$ 에서는 관계지시자(relationship designator) 중 1집단과 2집단 간 ' 관련 있는' 관계유형 속에 다양한 역할어가 정의되어 있어 이를 어휘화한 것이다.

셋째, 접근제어관계어휘 $\mathrm{FRAD}$ 모형만을 대 상으로 11 종의 서지개체와 이름 및 식별기호 간 ' 로 알려지다', ' 부여되다' 관계를 비롯하 여 12 종의 접근제어개체 간에 발생하는 관계유 형을 어휘화한 것이다.

넷째, 주제관계어휘는 FRBR, FRAD, RDA 
에서 개체 간 주제관계를 비교적 상세하게 정 의하고 있는 것은 FRBR뿐이며 FRAD, RDA 는 정의되어 있지 않거나 현재 개발 중에 있다. $\mathrm{FRBR}$ 의 정의에 의하면 제 $1,2,3$ 집단 모두 '저작'개체에 주제관계로 연결되어 있다.

아래 〈그림 1〉은 FRBR, FRAD, RDA의 서 지개체와 접근제어개체 23 종간의 다양한 관계 에서 추출한 4 종의 관계어휘의 트리플 구성도 를 나타낸 것이다.

11 종의 서지개체와 12 종의 접근제어개체들 은 $\mathrm{RDF}$ 트리플의 '주어(Subject)'와 '목적어 (Object)'로서 관계기술의 대상인 자원(resource) 의 역할을 하며, 관계어휘는 이들의 관계를 기술 할 술어(Predicate)로 활용될 것이다. 관계온톨 로지 구축 시 개체(entity) 들은 클래스(class)로 정의되고 이 개체들의 사례들은 인스턴스로 정 의된다. 또한 인스턴스의 외연은 객체속성 공리 를 통해 주어 클래스인 정의역과 목적어 클래스
인 치역 등이 정의된다. 따라서 burv 관계어휘 는 FRBR, FRAD, RDA에서 정의된 서지모델 링 이론에 따라 유형화된 관계개체로 정의역과 치역을 취하게 된다.

\section{3. burv 관계온톨로지 공리정의 및 어휘확장}

\section{1 공리정의}

본 절에서는 앞서 정의된 burv 관계어휘를 객체속성으로 정의하고 23 종의 서지세계 개체 들을 클래스로 정의하여, 온톨로지 저작도구인 Protégé를 통해 burv 관계온톨로지를 구축하 였다. 다음은 FRBR, FRAD의 개념모형에 기 반하여 온톨로지를 구축하는 과정 중 객체속성 의 공리표현을 중심으로 설명한 것이다.

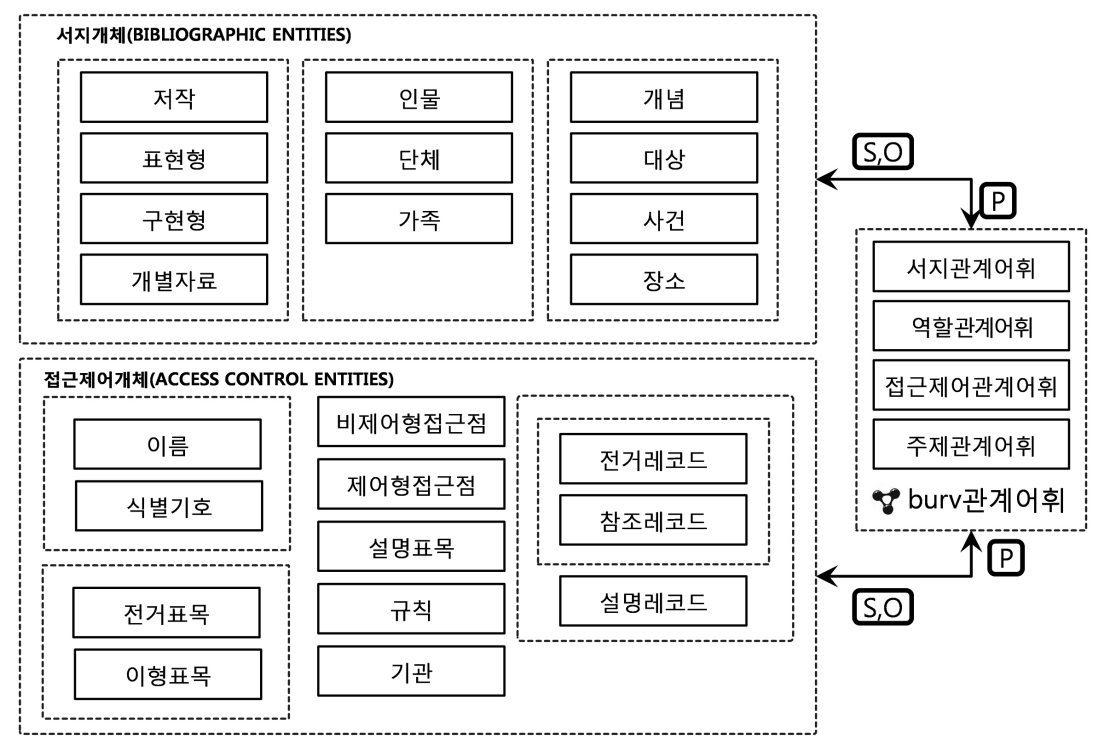

〈그림 1〉서지세계의 burv 관계어휘 및 개체 간 트리플 구조도 


\subsection{1 제 1 집단 내 개체 간 '주요관계' : 'owl:minQualifiedCardinality'}

제1집단 내 개체 간 주요관계는 저작, 표현 형, 구현형, 개별자료 간 발생하는 대표적 관계 로서 이를 표현하는 객체속성은 실현관계(저작 $\leftrightarrow$ 표현형)인 hasRealizer, 구현관계(표현형 ↔ 구현형) 인 hasEmbodiment, 사례관계(구현형 $\leftrightarrow$ 개별자료) 인 hasExemplar이다.

'has ' 순방향 관계를 살펴보면, 객체속성 hasRealizer는 실현관계(저작 $\rightarrow$ 표현형) 로서 정 의역을 저작 클래스로, 치역을 표현형 클래스 로 정의하였다. 객체속성 hasEmbodiment는 구현관계(표현형 $\rightarrow$ 구현형)로서 정의역을 표현 형 클래스로, 치역을 구현형 클래스로 정의하 였으며 객체속성 hasExemplar는 사례관계(구 현형 $\rightarrow$ 개별자료)로서 정의역을 구현형 클래스 로, 치역을 개별자료 클래스로 정의하였다. 또 한 순방향관계의 클래스 간 객체속성의 관계차 수는 각각 최소값 $0(\mathrm{Min}$ Cardinality $)$ )으로 제한하였다. 예를 들어 주어로서 정의역인 저 작 클래스에 대해 객체속성 hasRealizer의 목 적어로서 치역인 표현형 클래스의 인스턴스 출 현횟수를 $0 \ldots \mathrm{n}$ 으로 제약하여, 특정 저작 클래스 의 주어 인스턴스에 대해 표현형 클래스의 인 스턴스가 하나도 존재하지 않는 사례의 경우까 지 표현하였다. 나머지 구현관계와 사례관계도 동일하게 관계차수를 최소값 0 을 적용하였다.

이러한 객체속성 공리표현을 통해 서지세계 에서 흔히 발생할 수 있는 사례로서 1) 저작은 존재하나 표현형이 존재하지 않는 경우, 2) 표 현형은 존재하나 구현형이 존재하지 않는 경우, 3) 구현형은 존재하나 개별자료가 존재하지 않 는 경우까지도 표현할 수 있게 되었다.
만약 개념모형의 저작-표현형-구현형-개별 자료라는 클래스의 연속선 상에서 어느 한 클 래스의 인스턴스가 존재하지 않는 경우, 즉 저 작(無)-표현형, 저작-구현형, 표현형-개별자료 와 같은 관계는 개념모형의 관계유형에서 이에 대한 언급이 없어, burv에서 정의할 수가 없었 다. burv 관계온톨로지에서 이를 해결하는 한 가지 방법으로 클래스의 인스턴스에 공백, 값 없음, 인스턴스 없음, 확인불능 등을 의미하는 문자열(string)을 부여하여 연결함으로써 제1 집단 내 개체 간 연속성을 유지하였으며, 관계 어휘 부족문제를 해결하였다. 이와 같은 방법 을 통해 1) 표현형과 구현형은 존재하나 저작 이 존재하지 않는 경우(즉, 원작을 알 수 없는 경우), 2) 저작과 구현형은 존재하나 표현형이 존재하지 않는 경우(즉, 원저작의 표현형 원본 이 없고 다른 서지적 관계의 구현형만 있는 경 우), 3) 저작과 표현형은 존재하나 구현형이 존 재하지 않는 경우, 4) 저작, 표현형, 구현형은 존재하나 개별자료가 존재하지 않는 경우(즉, 자관에 원저작의 구현형을 소장하지 않은 경 우) 등을 온톨로지에서 표현할 수 있게 된다. 한편 (그림 2〉는 위 1), 2)에서 설명한 제1집 단 내 개체 간 관계 중 저작과 표현형 간 객체속 성의 관계차수 공리를 표현한 RDF/XML 문서 를 보여준 것이다.

\subsection{2 제 1 집단과 제 2 집단 개체 간 '역할관계' : 'rdfs:subPropertyOf'}

역할관계어휘는 제1집단에 대한 제2집단 개 체들의 역할관계를 정의한 어휘군이다. 역할관 계는 $\mathrm{FRBR}$ 에서는 책임관계라고도 하며 제 1 집 단 개체에 따라 제 2 집단의 역할유형이 결정된 


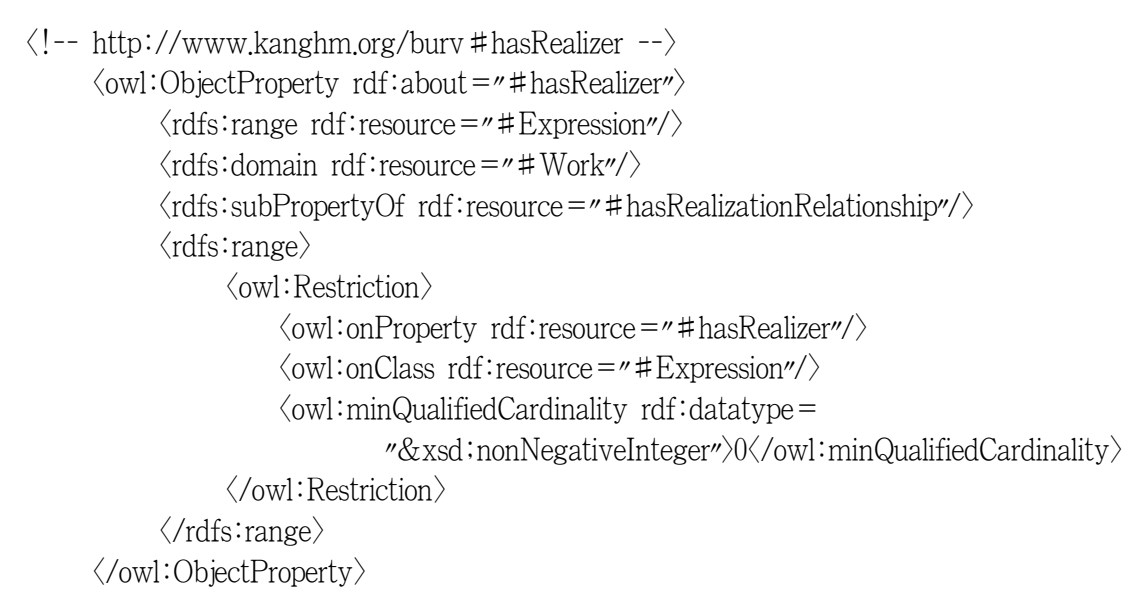

〈그림 2〉 저작과 표현형 간 '실현되다' 객체속성의 관계차수 공리(예)

다. 따라서 제1계층 객체속성 hasAssociated WithRelationship은 정의역으로 제1집단의 모 든 클래스를 가지며 치역으로 제 2 집단의 모든 클래스를 갖는다. 한편 제 2 계층의 객체속성은 그 어휘종류에 따라 정의역과 치역에 해당하 는 관련 클래스들이 달리 정의된다. 즉, 객체 속성 hasCreators는 주어로서 저작을 정의역으 로, 객체속성 hasContributors는 주어로서 표현 형을 정의역으로, 객체속성 hasDistributors, has
Manufacturers, hasPublishers는 주어로서 구 현형을 정의역으로, 객체속성 hasOwners는 주 어로서 개별자료를 정의역으로 가지며, 제 2 계층 의 객체속성들은 동일하게 목적어로서 제 2 집단 인물 - 단체 - 가족클래스를 치역으로 갖는다.

한편 〈그림 3〉의 객체속성 hasCreators는 하 위객체속성으로 hasArchitect, hasArtist, has Author 등으로 계층관계를 이루는데 이들은 모 두 상위 객체속성 hasCreators가 갖는 정의역과

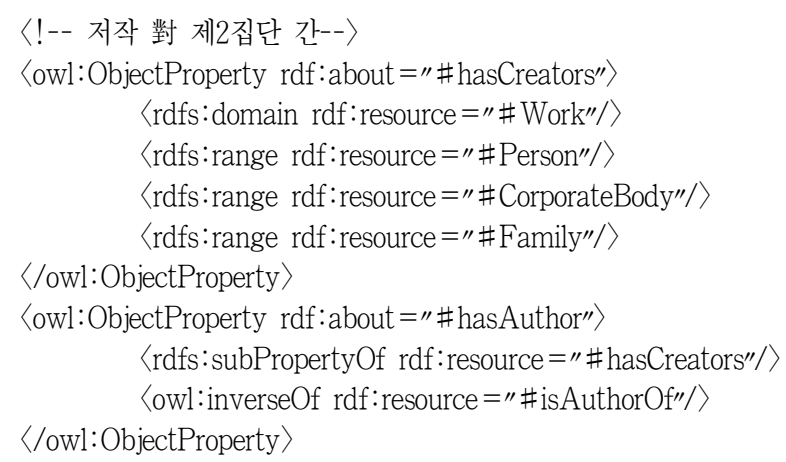

〈그림 3〉저작과 제2집단 개체 간 '역할관계' 및 객체속성의 계층관계 상속 
치역을 상속받는다. 또한 객체속성 has Author 는 하위객체속성 hasScreenwriter를 갖는데 마 찬가지로 hasScreenwriter는 hasAuthor의 정 의역과 치역을 상속받는다.

\subsection{3 제 2 집단과 이름 개체 간 '접근제어관계'}

$$
\text { : 'owl:minQualifiedCardinality' }
$$

인물 - 단체 클래스의 인스턴스는 이름 클래스 의 여러 인스턴스를 $1: n$ 대응차수를 가질 수 있 는데, 인물 - 단체 인스턴스는 반드시 하나 이상 의 공식이름(hasOfficialName)을 가져야 한다. 왜냐하면 이름 - 단체 클래스의 인스턴스는 이름 클래스 인스턴스 중 본명이든 필명이든 가명이 든 널리 알려진 특정이름 하나를 기본형식으로 반드시 최소 하나 이상은 가져야 하기 때문이다. 이 공식이름은 인물 - 단체 클래스에서 유일하게 식별하는 기본형식으로서 다른 클래스의 인스턴 스와 관계를 맺어간다. 따라서 인명 - 단체 $\rightarrow$ 이 름 관계에서는 owl:minQualifiedCardinality를 '1'로 지정하였다. 즉 〈그림 4>에서 보듯 인스턴 스의 출현횟수가 반드시 하나는 출현해야 하는
최소 $1(1 \ldots \mathrm{n})$ 이라는 의미이다.

\subsection{4 제2집단과 이름 개체 간 '접근제어관계': 'owl:InverseFunctionalProperty'}

한편 객체속성 $\mathrm{P}$ 가 owl:InverseFunctional Property인 경우는 모든 $\mathrm{y}$ 에 대해서 $\mathrm{P}(\mathrm{x}, \mathrm{y})$ 의 $\mathrm{x}$ 가 1개로 규정되며 $\mathrm{y}$ 에 대해서 1 개의 $\mathrm{x}$ 가 대응 하는 역함수(IFP) 관계에 있다고 한다. 예를 들 어 〈그림 5〉에서 보듯 스웨덴을 대표하는 아동 문학작가 Astrid Lindgren이 Astrid Ericsson, Anna Ericsson 등 두 개의 변경 전 이름을 사용 하고 있었는데, 두 명의 이름(주어) 인스턴스에 대해 역함수 속성값을 갖는 isEarlierNameOf 객체속성(술어)이 특정 1 명의 인물(목적어)의 인스턴스를 지시하면, 해당 주어들은 동일한 인스턴스임을 묵시적으로 의미한다.

이렇게 동일 인물에 대해 여러 이름이 알려져 있는 경우 isLaterNameOf, isPseudonymOf 등 해당 객체속성에 역함수 객체속성 공리특질을 적용함으로써 다양한 이형식의 이름을 갖는 특 정 인물을 지시할 수 있다.

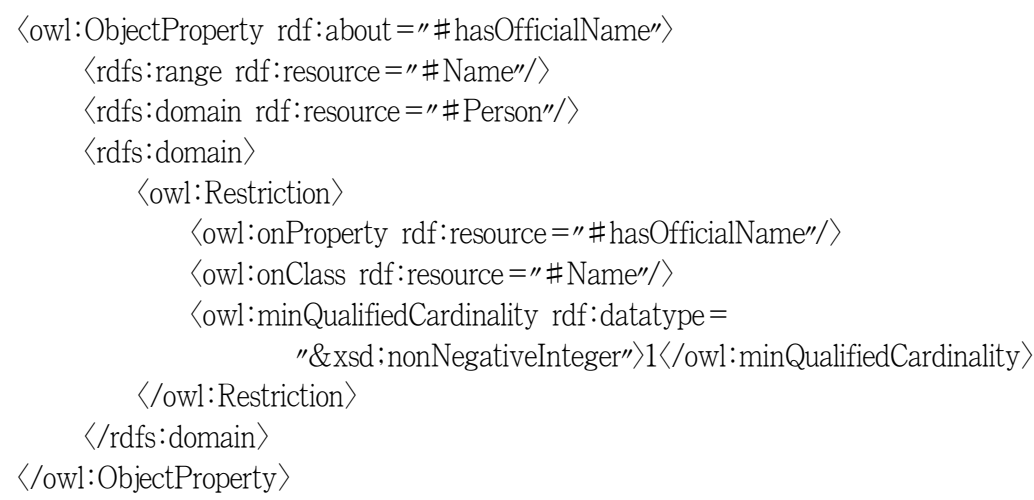

〈그림 4〉인물개체의 기본형 이름 선언과 대응차수 정의 


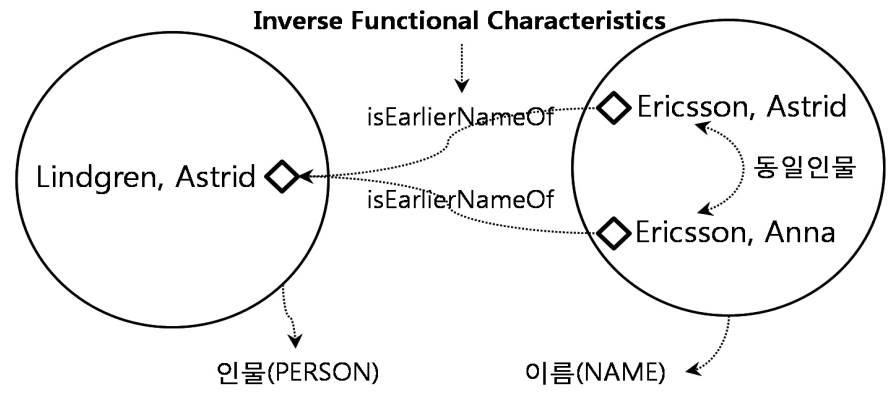

〈owl:ObjectProperty rdf:about=" \#isEarlierNameOf"〉

$\langle$ rdf:type rdf: :esource $="$ \&owl; InverseFunctionalProperty" $/\rangle$

$\langle$ rdfs:domain rdf:resource $="$ \#Name" $/\rangle$

$\langle$ rdfs: range rdf:resource $=" \#$ Person" $/\rangle$

〈/owl:ObjectProperty

〈그림 5〉객체속성의 역함수(IFP) 특질 정의 및 RDF/OWL 구문

\section{2 관계어휘 확장}

\subsubsection{FOAF 어휘스키마}

burv 관계온톨로지에 $\mathrm{FOAF}$ 어휘스키마를 병합하는 주요 목적은 FOAF 인물정보 범주에 속해 있고 인물과 인물 간 '알고 있다' 관계를 표 현하는 foaf:knows 객체속성을 병합하여 burv 에서 표현할 수 없었던 인물과 인물 간의 인간 관계를 기술하기 위함이다. 이렇게 함으로써 어 느 특정저자가 특정주제영역에서 지인관계를 유지하면서 함께 저작활동을 했던 관련 주변 저 자들의 인물정보와 그들의 저작들을 동시에 기
술하고 제시할 수 있기 때문이다.

병합된 $\mathrm{FOAF}$ 의 여러 클래스와 객체속성 중 burv 관계온톨로지 어휘 확장과 관련하여 인물과 인물 간 인적관계 기술을 위한 핵심 어 휘인 foaf:knows 객체속성과 foaf:Person 클 래스에 대해서만 공리 조정을 하였다. 즉, 객체 속성 foaf:knows의 정의역과 치역으로서 foaf: Person 클래스는 burv 관계온톨로지의 burv: Person 클래스와 의미적으로 동등한 관계에 있 으므로, 〈그림 6〉과 같이 foaf:Person 과 burv: Person 클래스에 대해 'equivalent class' 클래 스 공리를 사용하여 정의해 주었다.

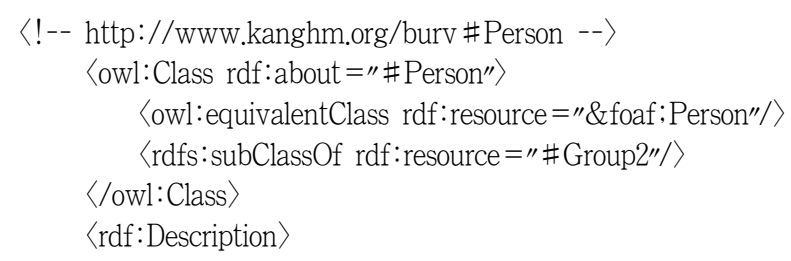

〈그림 6〉 burv:Person과 foaf:Person 클래스의 등치관계 정의 


\subsubsection{RELATIONSHIP 어휘스키마}

RELATIONSHIP 어휘스키마는 앞에서 다 룬 $\mathrm{FOAF}$ 어휘스키마에서 ' 를 알고 있다'라 는 의미인 객체속성 foaf:knows의 하위객체속 성으로서 인물과 인물 사이에서 발생되는 다양 한 인간관계를 34 종의 관계어휘를 사용하여 상 세하게 표현할 목적으로 정의된 것이다.

이때 RELATIONSHIP 어휘스키마의 객체 속성 34종에는 burv 관계온톨로지에서 사용된 객체속성과 의미적으로 동일하게 정의되어 있 는 어휘들이 있어 어휘의 의미중복을 방지하기 위해 객체속성 공리 조정을 하였다.

burv의 인물-인물 간 관계를 표현하는 객체 속성 7종 중 합작관계와 부모/자식관계, 형제 관계 등 3 종은 relationship의 객체속성 3 종과 의미적으로 동일하여 owl:equivalentProperty 공리 표현을 통해 등치관계로 정의하였다.

〈그림 7〉은 객체속성 relationship:collaborat esWith가 burv 객체속성인 \#hasCollaborative Relationship 및 \#isCollaborativeRelationship Of와 owl:equivalentProperty 속성을 사용하여
등치관계공리 정의사례를 보여준다.

이렇게 foaf:knows와 RELATIONSHIP을 통해 확보된 34 종의 객체속성은 burv 관계어 휘에서 추가로 '인물관계어휘'군을 구성하였고 이후 Xburv 관계온톨로지에서 인물망 온톨로 지를 구축하는데 활용하였다.

\subsection{3 vCARD 어휘스키마}

온톨로지 저작도구인 Protégé를 통해 burv 와 $\mathrm{vCARD}$ 의 상이한 어휘스키마에서 특정인 물을 연결하였다. 즉 burv의 인물 인스턴스 에 대한 속성선언(Property assertion)에서 데 이터속성 선언(Data Property assertion)으로 $\mathrm{vCARD}$ 의 데이터속성인 uid와 $\mathrm{fn}$ 을 선택하고 직접 리터럴 값(예: 'P1', '박목월')을 입력하였 다. 이는 관계형 $\mathrm{DB}$ 에서 외래키(foreign key)와 유사한 기능을 한다. 〈그림 8〉을 보면 이름클래 스의 특정 인스턴스 $\mathrm{N} 1$ 은 기본형이름(burv: hasOfficialName)으로 인물클래스의 인스턴스 $\mathrm{P} 1$ 과 연결되어 있다. 이때 N1은 데이터속성 hasString을 통해 리터럴 '박목월’을 갖고 있다.

〈owl:ObjectProperty rdf:about="\&relationship; collaboratesWith"〉

$\langle$ rdf:type rdf:resource="\&owl;:SymmetricProperty" $/\rangle$

$\langle$ rdfs:label xml:lang $="$ "en"

\rangle collaborates with $\langle/$ rdfs:label $\rangle$

$\langle$ rdfs:isDefinedBy rdf:datatype $=" \& x s d$; anyURI"

$>$ http://purl.org/vocab/relationship///rdfs:isDefinedBy $\rangle$

$\langle$ owl:equivalentProperty rdf: resource $="$ \# hasCollaborativeRelationship" $/\rangle$

$\langle$ owl: equivalentProperty $\mathrm{rdf}$ : resource $=" \#$ isCollaborativeRelationshipOf $\prime \prime \prime\rangle$

$\langle$ rdfs:range rdf:resource $=" \&$ foaf:Person" $/\rangle$

$\langle$ rdfs:domain rdf:resource $=" \&$ foaf:Person" $/\rangle$

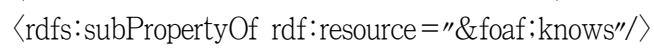

〈/owl:ObjectProperty>

〈그림 7〉 burV와 RELATIONSHIP의 '협력관계' 의미매핑 결과 
$\langle$ !-- http:/www.kanghm.org/burv \#P1 -〈owl:Thing rdf:about="\&burv;P1"〉 $\langle$ rdf:type rdf:resource $="$ \#Person" $/\rangle$ 〈hasName〉P1_박목월〈/hasName〉 $\langle$ vCard:uid $\rangle \mathrm{P} 1\langle/ \mathrm{vCard}:$ uid $\rangle$ 〈vCard:fn〉박목월〈/vCard:fn〉 $\langle$ hasOfficialName rdf:resource $="$ \&burv $; \mathrm{N1} " /\rangle$ 〈/owl:Thing

$\langle$ !-- http://www.kanghm.org/burv \#N1 -〈owl: Thing rdf:about $="$ \#N1">

$\langle$ rdf:type rdf:resource $="$ \#Name" $/\rangle$

〈burv:hasString rdf:datatype="\&xsd;string"'박목월〈/burv:hasString $\rangle$ 〈/owl: Thing >

〈그림 8〉 burv 인물 인스턴스와 VCARD 인물 인스턴스 간의 연결구조

한편 인물클래스의 특정 인스턴스인 'P1'에 대 해 속성선언을 $\mathrm{vCARD}$ 의 데이터속성인 uid와 fn에 대한 리터럴 값으로 'P1'과 '박목월’을 부 여하여 어플리케이션이 burv의 인물과 연결된 $\mathrm{VCARD}$ 의 인물을 동일하게 식별하여 연결될 수 있도록 하였다.

지금까지 Xburv 관계온톨로지에서 인물정 보 기술을 위해 병합한 어휘스키마들의 주요 기능들을 살펴보면, $\mathrm{vCARD}$ 는 특정인물에 대 한 이름, 주소, 직장, 연락처 등 기본신상정보를 기술하고, burv의 접근제어관계어휘를 통해 특 정 인물에 대한 다양한 형식의 이름정보를 기 술하고, foaf:knows를 통해 특정인물이 알고 있는 사회적 인물망 정보를 기술하고, 마지막 으로 RELATIONSHIP을 통해 인물관계정도 와 유형에 대한 상세한 정보를 기술하는데 사 용될 수 있다.

이렇게 vCARD, burv, foaf:knows, RELATIONSHIP 어휘스키마 병합을 통해 확보된 객 체속성들은 burv 관계어휘에서 추가로 '인물정 보관계어휘'군을 구성하였고 이후 Xburv 관계 온톨로지의 하위온톨로지로서 인물정보온톨로
지를 구축하는데 활용될 것이다. 이 인물정보온 톨로지는 기존 인명전거거레코드에서 이름의 전거개념을 배제하고, 다양한 이름형식을 대등 한 접근점으로 삼는 접근점제어레코드 개념을 도입한 온톨로지가 될 것이다.

\section{Xburv 관계온톨로지 시스템 구축과 활용}

\section{1 개발환경 및 시스템 구성도}

Xburv 관계온톨로지 시스템 개발환경을 살 펴보면, 운영체제는 Windows XP Home Edition을 사용했으며 웹서버와 서블릿 컨테이 너는 Jarkarta-tomcat(ver.5.5.5)을 사용하였 다. 개발언어는 JAVA(ver. 6.0)이며, 자바플랫 폼을 기반으로 하는 대표적인 자바 및 웹 프로그 래밍 저작도구인 Eclipse Platform(ver. 3.3.2) 을 사용하였다.

웹 프로그래밍은 JSP를 사용하여 인스턴스 관리시스템, $\mathrm{SPO}$ 트리플관리시스템, 이용자질 
의시스템, 관리자시스템 등의 웹 모듈을 구현 하였다. 또한 이용자질의시스템에서 유형화된 SPARQL 질의문은 Java Script 프로그래밍 소스 속에 함께 구성하였다. 온톨로지 시각화 도구는 Prefuse라는 Java Applet Viewer를 사용하였으며, 웹 브라우저는 $\mathrm{W} 3 \mathrm{C}$ 의 웹 표준 적용에 비교적 충실한 Mozilla Firefox 3.1 버 전에 최적화하여 개발하였다.

〈그림 9〉는 Xburv 관계온톨로지 시스템의 기본 구성도이다. 전체 시스템은 인스턴스관리 시스템, $\mathrm{SPO}$ 트리플관리시스템, 온톨로지질의 시스템 등 3 종의 주요 하위시스템으로 구성된 다. 주요 시스템 처리흐름으로는 우선, 기존 레
거시시스템으로부터 추출한 별도의 관계형 $\mathrm{DB}$ 기반 개체별 인스턴스 테이블을 완성하고 이를 인스턴스관리시스템으로 반입하여 온톨로지 기반의 인스턴스를 생성한다. 생성된 인스턴스 들은 주어(Subject), 목적어(Object)로 각각 사용되며 Xburv는 술어(Predicate)로서 SPO 트리플관리시스템에 의해 $\mathrm{RDF}$ 트리플을 생성 하여 $\mathrm{RDF}$ 스토어인 $\mathrm{SDB}$ 에 저장된다. 온톨로 지 질의시스템을 통해 전송된 $\mathrm{SPARQL}$ 질의 문은 Joseki Server가 ARQ로 전달하며 $\mathrm{ARQ}$ 는 $\mathrm{SDB}$ 내 저장된 트리플을 검색하고 그 질의 결과는 Joseki Server를 거쳐 JAVA 애플릿 뷰어인 Prefuse 시각화도구를 통해 윕브라우

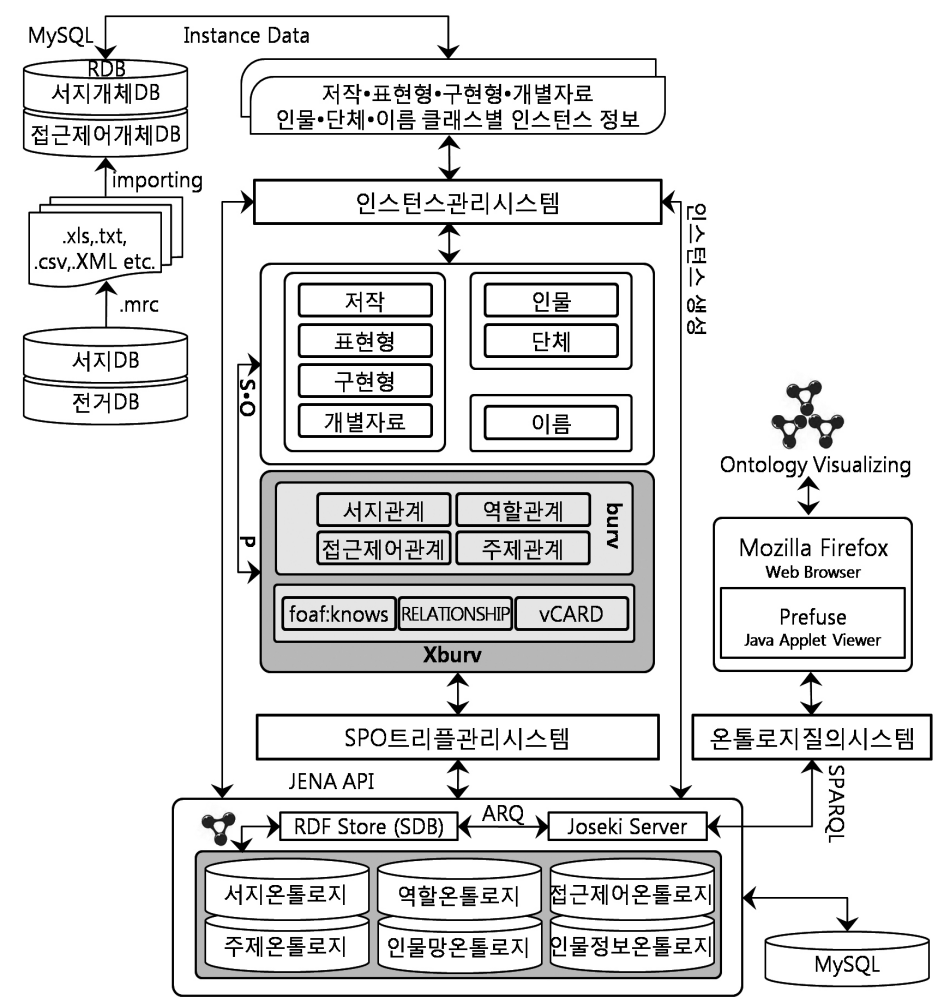

Xburv RELATIONSHIP ONTOLOGY

〈그림 9〉Xburv 기반 "청록파 관계온톨로지" 시스템 구성도 
저에 디스플레이 된다.

본 시스템에는 서지세계 23종의 모든 개체 클래스에 대해 주어 $(\mathrm{S})$, 목적어 $(\mathrm{O})$ 클래스로서 관계온톨로지 시스템 기본스키마 구조에 반영 하였으나, 아래 〈그림 9〉에서 보는 바와 같이 실제 ‘청록파 관계온톨로지’를 구축하는데 저 작, 표현형, 구현형, 개별자료, 인물, 단체, 이름 개체 클래스 등 7종의 사용된 개체클래스를 중 심으로 인스턴스를 구축하였다. 인물 및 단체 클래스의 인스턴스는 식별기호와 기본형이름 정보가 정의되어 있고, 이름 개체클래스의 인 스턴스는 인물 - 단체의 기본형이름을 비롯하 여 다양한 이형식 이름이 정의되어 있다. 한편 술어 $(\mathrm{P})$ 로서 활용하는 다양한 객체속성군 즉 관계어휘군은 서지관계어휘, 역할관계어휘, 주 제관계어휘, 접근제어관계어휘 등 4 종의 burv 객체속성과 여기에 추가된 인물관계어휘, 인물 정보관계어휘 2종을 합한 총 6 종으로 구성된 Xburv 객체속성이 사용되었다. Xburv에 의해 주어, 목적어로 정의된 선언문인 $\mathrm{RDF}$ 트리플들 은 그 관계개체와 관계어휘의 종류에 따라 서 지온톨로지, 역할온톨로지, 접근제어온톨로지, 주제온톨로지, 인물망온톨로지, 인물정보온톨로 지 등 6종의 온톨로지로 구축하였으며 이들은 $\mathrm{RDF}$ 트리플 저장소인 $\mathrm{SDB}$ 에 저장된다.

\section{2 주요 하위시스템}

\subsection{1 인스턴스관리시스템}

인스턴스관리시스템은 온톨로지 내 클래스 의 멤버가 되는 인스턴스를 클래스별로 각각 생 성하기 위한 시스템이다. 생성된 인스턴스들은 $\mathrm{RDF}$ 트리플 지정 시 주어 $(\mathrm{S})$, 목적어 $(\mathrm{O})$ 로 활
용되며 $\mathrm{RDF}$ 트리플 저장소 즉 $\mathrm{SDB}$ 에 저장된 다. 주요 기능은 기존 MARC 형식의 데이터를 MySQL기반 인 RDB 테이블 내에 개체 클래스 별로 인스턴스 데이터(Instance Data)를 생성 하고, 생성된 인스턴스 데이터를 온톨로지 상의 $\mathrm{RDF}$ 저장소인 $\mathrm{SDB}$ 에 인스턴스(Instance)로 반입하는 기능을 담당한다.

\subsubsection{SPO트리플관리시스템}

$\mathrm{SPO}$ 트리플관리시스템은 Xburv 객체속성 을 사용하여 주어 - 목적어 개체 클래스의 인스 턴스 간 관계유형과 관계기술을 저장하여 다양 한 온톨로지를 생산하는 '관계기술목록'이라는 업무기능을 수행하는 핵심시스템이다. 따라서 인스턴스관리시스템을 통해 생성된 인스턴스 를 특정주제 분야의 다양한 지적관계를 $\mathrm{SPO}$ 트 리플로 표현하고 기술하기 위한 시스템 환경을 제공한다. 일반적으로 도서관리통합시스템 중 서지기술을 통한 저록을 생산하는 목록시스템 처럼, 온톨로지 환경에서 서지세계 개체 간의 관계기술을 통해 소위 $\mathrm{SPO}$ 트리플 저록 $\mathrm{SPO}$ Triple entry)을 생산하는 시스템으로 비유될 수 있다.

$\mathrm{SPO}$ 트리플관리시스템은 해당 주어와 목적 어 간 관계개체유형에 따라 서지관계어휘는 서 지온톨로지를, 역할관계어휘는 역할온톨로지를, 접근제어관계어휘는 접근제어온톨로지를, 주제 관계어휘는 주제온톨로지를, 인물관계어휘는 인 물망온톨로지를, 인물정보관계어휘는 인물정보 온톨로지 등 6 종의 온톨로지를 구축한다. 또한 $\mathrm{SPO}$ 트리플관리시스템을 이용해 특정주제 분 야의 다양한 지적관계를 기술한 온톨로지 구축 을 위해, 1930 40년대 한국문학의 대표적인 시 
파인 청록파 시인 3 인을 중심으로 '청록파 관계 온톨로지’를 구축하였다.

\subsection{3 온톨로지 질의시스템}

구축된 청록파 관계온톨로지에 대한 SPARQL 질의 및 질의결과를 제시하는 시스템으로 유형 화된 질의시스템과 고급 SPARQL 질의시스템 이라는 두개의 하위시스템으로 구성하였다. 우 선 유형화된 질의시스템은 온톨로지 환경에서 확장된 목록기능의 구현 가능성과 그 결과를 확 인하기 위해, 청록파 관계온톨로지를 특정 질의 목적에 따라 Java 스크립트 프로그래밍에 내장 되어 구성된 5 종으로 유형화 된 $\mathrm{SPARQL}$ 질의 문의 수행과 온톨로지 시각화 도구를 통해 비 주얼한 질의결과를 확인할 수 있도록 해 준다. 즉, 1) 특정 저자의 모든 저작, 2) 동일 저작의 여러 상이판, 3) 사회적 인물망으로 연결된 저 자들의 모든 저작, 4) 특정 저자의 알려진 여러 이름, 5) 객체속성의 계층관계 상속을 이용한 추론 등으로 유형화된 $\mathrm{SPARQL}$ 질의문을 작 성하였다. 다음으로 고급 $\mathrm{SPARQL}$ 질의시스 템은 이용자가 명령어라인 방식으로 SPARQL 질의문을 직접 작성하여 그 질의결과를 온톨로 지 시각화도구 뿐만 아니라 텍스트기반의 RDF 트리플 결과보기 기능으로 확인할 수 있도록 하 는 시스템이다. 특히 이 시스템은 RDFS 속성 상속을 이용한 하위수준의 추론 질의(inference query) 기능을 수행하는 것을 핵심목적으로 한다.

구현된 Xburv 관계온톨로지 시스템을 활용하 여 1930 40년대 당시 한국문학의 대표적 문인이 었던 박목월, 조지훈, 박두진 청록파 시인 3 인을
중심으로 ‘청록파 관계온톨로지’를 구축하였다.

\subsection{SPARQL 질의 및 온톨로지 시각화}

\subsection{1 특정저자의 모든 저작}

목록의 가장 기본적인 기능 중 하나로서 제 1 집단 개체와 제 2 집단 개체 간 책임관계에 대한 질의이다. 즉 특정저자(인물 - 단체) 가 저작, 표 현형, 구현형, 개별자료 개체에 대해 역할관계 어휘로 기술된 모든 책임관계를 보여주기 위함 이다.

특정저자는 저작에 대해 창작자(hasCreators), 표현형에 대해 기여자(hasContributors), 구 현형에 대해 배포자(hasDistributors), 제조자 (hasManufacturers), 출판자(hasPublishers), 개별자료에 대해 소유자(hasOwners)의 역할 을 수행하는데 그 하위 역할관계어휘로 보다 세 부적인 역할이 기술된 관계를 제시하고자 한다.

청록파 관계온톨로지에서는 박목월, 조지훈, 박두진 청록파 3 인과 단체인 청록파의 제 1 집단 에 대한 모든 책임관계를 보여준다. 또한 동명 이인으로서 타 분야 박목월, 박영종, 조지훈, 박 두진 등의 모든 관련 저작을 분리하여 시각화 한다.

〈그림 10〉은 시인 박목월(P1)이 창작한 모 든 저작들을 제시하고 있다. 저작은 추상적 단 계로서 텍스트로 표현되고 있으며, 이를 실현한 원작과 기타 파생된 표현형은 이미지로 표현되 고 있다. 또한 저작의 하위 수준의 개체로서 표 현형, 구현형, 개별자료 단계까지의 관계유형들 도 구체적으로 보여준다. 


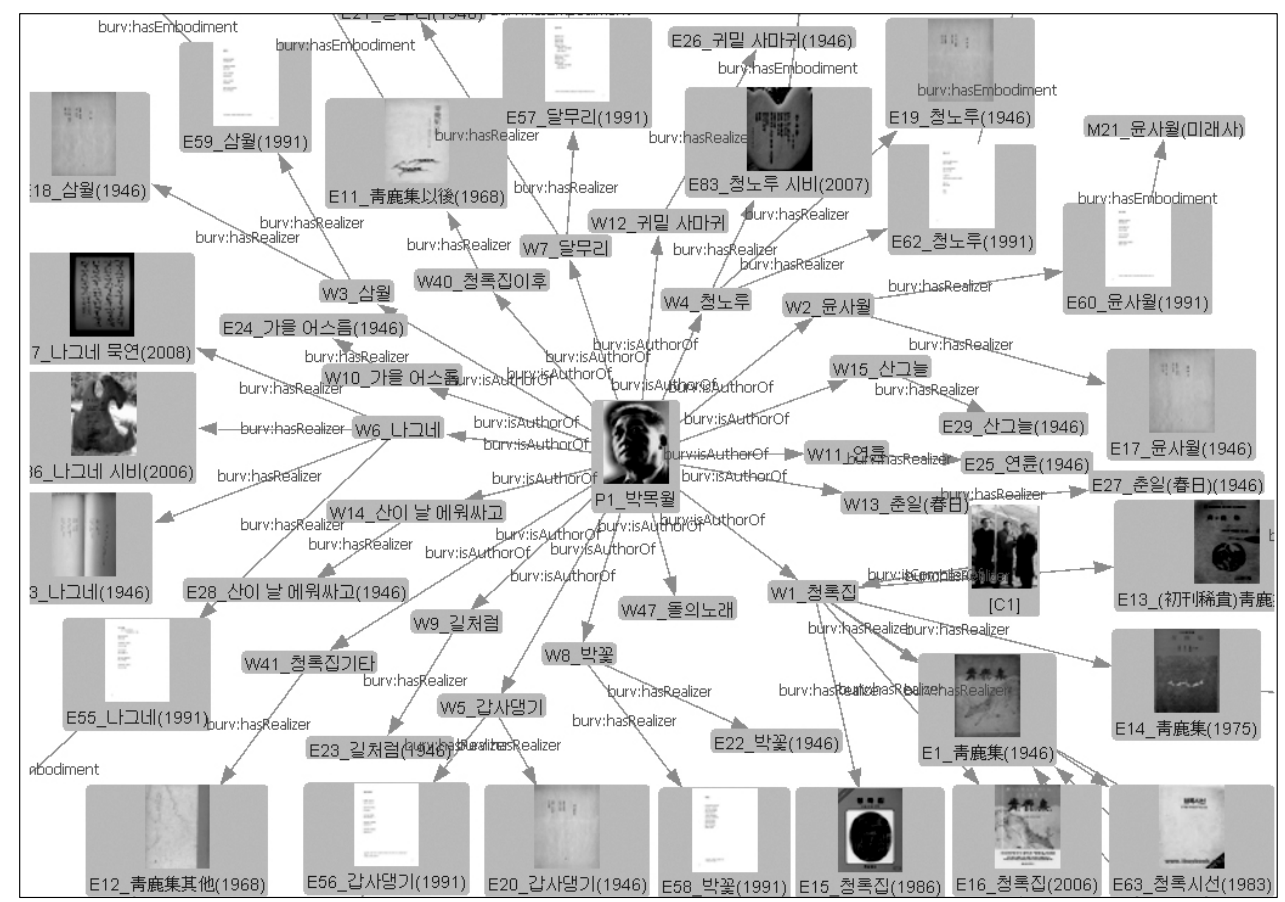

〈그림 10〉특정저자의 모든 저작: ‘박목월'

\subsection{2 동일저작의 여러 상이한 판}

제 1 집단 내에서 특정개체와 다른 개체 간 서 지적 관계에 대한 질의이다. 사용된 객체속성 은 서지관계어휘이다. 동일저작에 대해 수직적 수준에서 저작, 표현형, 구현형, 개별자료 간 계 층적 관계뿐만 아니라 저작 1 과 저작 2 등 수평 수준에서의 서지적 관계를 갖는 관련 모든 저 작을 보여주기 위함이다.

재판, 개작, 해설판과 같이 '청록집'과 서지적 으로 관련된 모든 상이판을 보여준다. 예를 들 어 청록집의 후속저작인 '청록집 이후’, ‘청록집 기타' 간 저작, 표현형, 구현형, 개별자료 수준 에서의 후속관계와, 청록집 내 '나그네', '승무' 와 같은 독립개별 저작의 여러 상이판(악보, 녹 음자료 등)을 보여준다. 또한 합집인 청록집 내
개별저작(39편) 과의 전체/부분관계 등도 제시 한다.

〈그림 11〉을 보면, 원저작인 청록집(W1)은 1946년에 실현(E1) 되었으며 을유문화사에서 구 체화(M1)되었고 여러 구현형 중 사례로서 개별 자료(811.6-6-1251-16)로 소장되고 있다. 이후 원저작의 후속저작으로 청록집이후(W40)와 그 후속저작으로 청록집기타(W41) 가 창작되었다. 또한 원저작(W1)으로부터 같은 해에 문학사상 사에서(初刊稀貴本)青鹿集(E13)이, 1975년 삼 중당에서도 청록집(E14), 1986년 다시 삼중당에 서 청록집 재판(E15)이 발행되었으며, 2006년 을유문화사에서는 원작의 표현형 $(\mathrm{E} 1)$ 에 대해 청 록집의 개정판 $(\mathrm{E} 16)$ 을 발행하였다. 


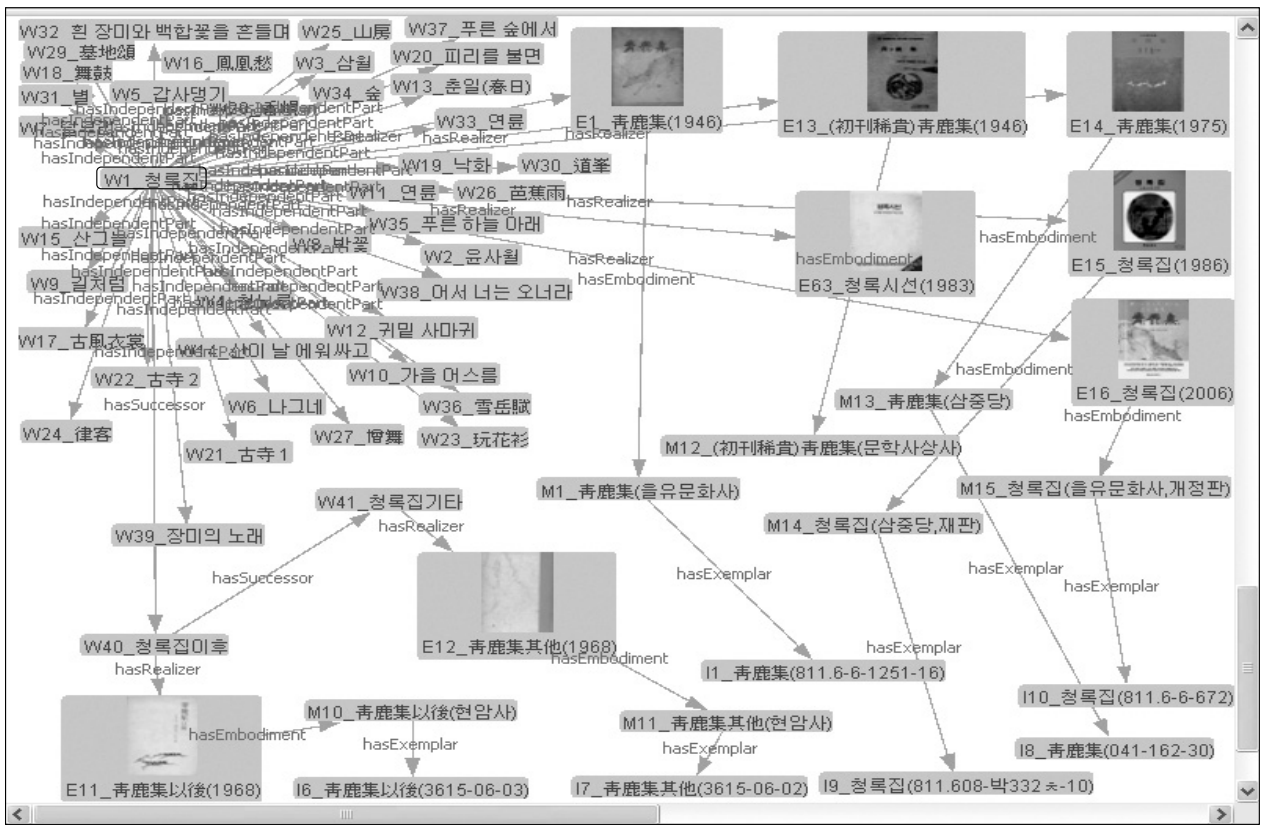

〈그림 11〉 동일저작의 여러 상이판: ‘청록집'

\subsection{3 사회적 인물망으로 연결된 저자들의} 모든 저작

제2집단 내 특정한 인물개체가 둘 이상의 인 물개체 간 사회적 인물망 관계를 맺고 있는 인 적 네트워크에 대한 질의이다. 또한 해당 인물 과 제1집단 간의 책임관계에 대한 질의를 포함 하여, 인물망을 맺고 있는 특정인물의 관련저작 까지 보여주기 위한 질의이다. 인물망 온톨로지 를 위해 사용된 관계어휘는 burv, foaf:knows, RELATIONSHIP 어휘스키마를 포함하고 있 는 인물관계어휘와 서지관계어휘, 역할관계어 휘이다. 예를 들어 청록파 시인 박목월, 박두진, 조지훈 3 인을 중심으로 이들과 관련된 타 인물 간의 인간관계와 모든 관련 저작을 보여줄 수 있다.

〈그림 12〉를 보면 박목월(P1)이 알고 있는 사 람은 조지훈(P2), 박두진(P3)외에 김동리(P5),
정지용 $(\mathrm{P} 4)$, 박동규 $(\mathrm{P} 41)$ 이다. 박동규 $(\mathrm{P} 41)$ 는 아버지와 아들(W69)을 박목월(P1) 과 함께 창작 (hasAuthor) 하였고, 정지용(P4)은 문장지(W60) 발간의 후원자역할(hasSponsor ingBody)을 하 였음을 보여준다.

\subsection{4 특정저자의 알려진 여러 이름}

제 1 집단 중 인물개체와 접근제어영역의 이름개 체 간 다양한 알려진 이형관계를 보여주기 위함이 다. 사용된 객체속성은 접근제어관계어휘이며 인 물의 기본형이름은 객체속성 hasOfficialName으 로 연결된 이름 인스턴스와 인물 인스턴스가 된다. 기존 MARC 환경에서의 인명전거파일과 관련이 있는 온톨로지 질의이나 전거의 개념이 배제되고 동명이인을 식별하여 제시해 준다.

예를 들어 인물 클래스의 인스턴스인 박목월 (P1)은 이름 클래스에서 박목월 (N1), 박영종 


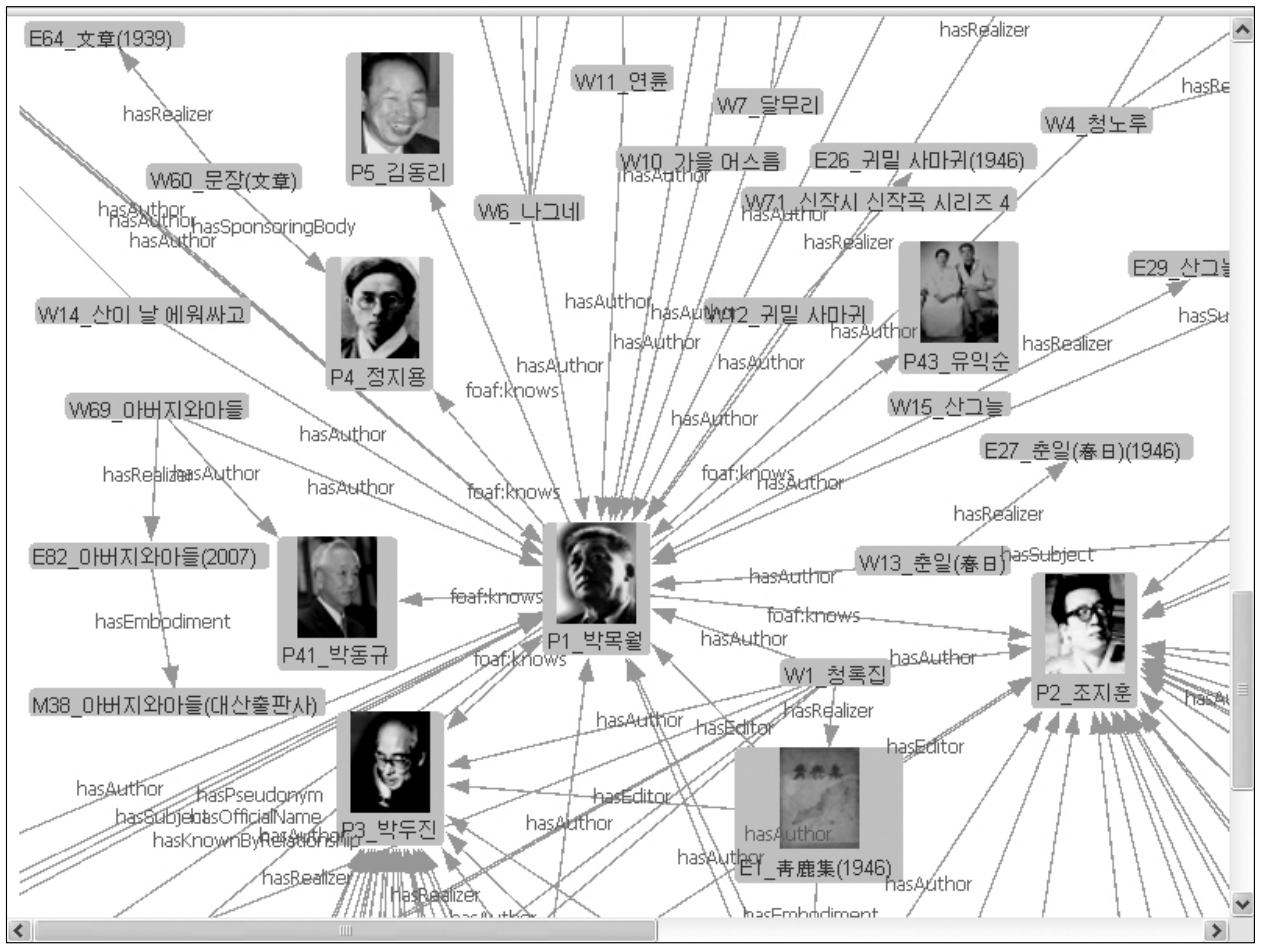

〈그림 12〉사회적 인물망으로 연결된 저자들의 모든 저작: '박목월'

(N2), 朴泳鍾 (N3), 木月 (N4), 목월(N5), 박 창용(N6) 등과 동일인물에 대한 다양한 이형 식 이름관계를 이루며 이중 이름 인스턴스는 박목월 $(\mathrm{N} 1)$ 은 인물 인스턴스 박목월(P1)과 hasOfficialName으로 연결돼 기본형 이름으로 식별된다.

〈그림 13〉에서 보는 바와 같이 인물 클래스의 인스턴스인 박목월(P1)은 이름 클래스에서 공 식명인 박목월 $(\mathrm{N} 1)$, 어렸을 적 실명인 박영종 $(\mathrm{N} 2)$, 朴泳鍾 $(\mathrm{N} 3)$, 木月 $(\mathrm{N} 4)$, 목월 $(\mathrm{N} 5)$, 직 장생활시 사용한 이형이름 박창용(N6) 등과 같 이 동일인물에 대한 다양한 이형식 이름관계를 이루며 이중 이름 인스턴스는 박목월(N1)은 인 물 인스턴스 박목월(P1)과 hasOfficialName으 로 연결되어 기본형 이름으로 식별된다. 한편 동
명이인인 박목월 $(\mathrm{P} 72)$ 은 시인 박목월(P1) 과는 별개의 인물임을 나타내기 위해 분리된 시각화 로 화면제시가 된다.

\subsection{5 객체속성의 계층관계 상속을 이용한 추론}

$\mathrm{SPO}$ 관리시스템을 통해 명시적으로 생성하 지 않은 RDF 트리플에 대한 객체속성 질의를 시도함으로써 객체속성의 계층상속을 통한 SPARQL 질의의 낮은 단계의 추론기능을 보여 주기 위한 질의이다. 청록파 관계온톨로지는 각 각의 모든 어휘군에서 모두 최하위 단계의 어휘 (객체속성)로 트리플을 생성했었다. 이때 명시 적으로 사용되지 않은 바로 상위단계의 객체속 성에 대한 SPARQL 질의결과를 보여준다. 예 


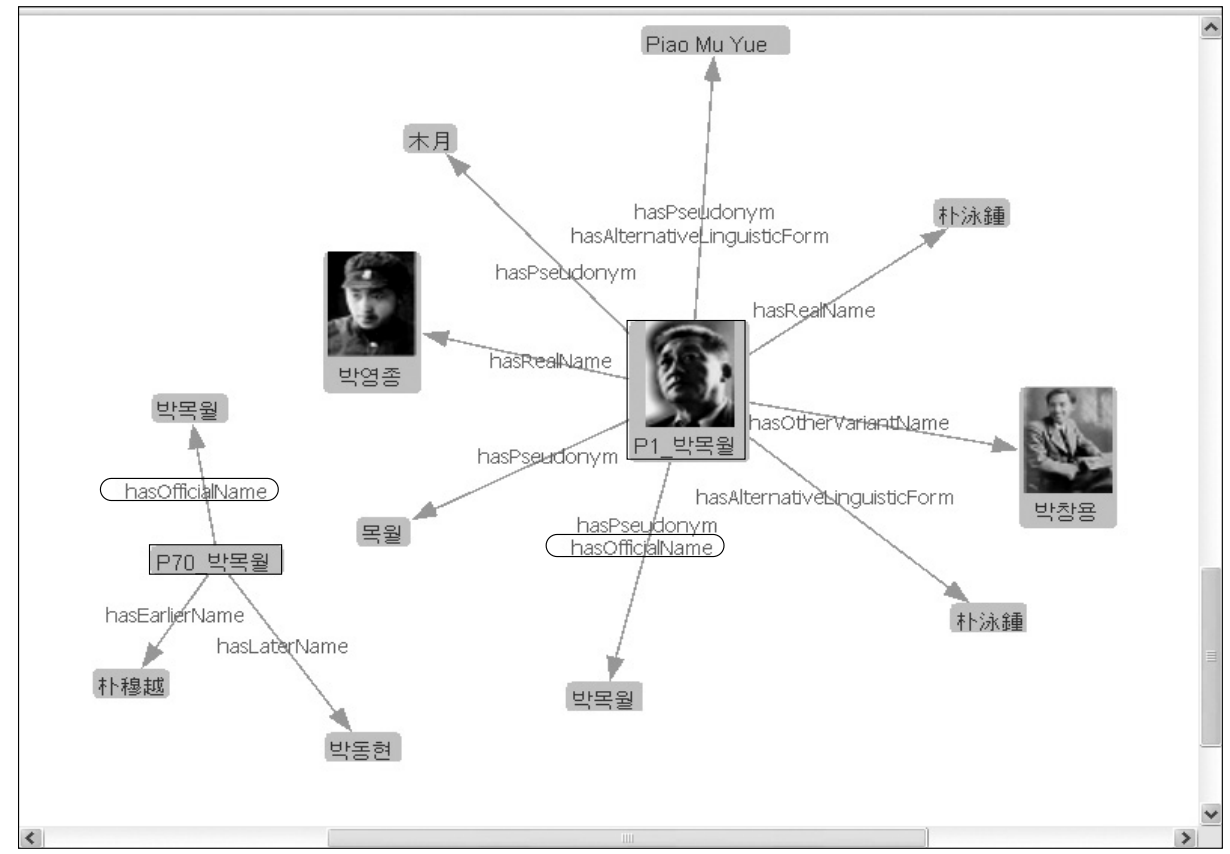

〈그림 13〉 특정저자의 알려진 여러 이름: ‘P1_박목월', ‘P70_박목월’ 사례

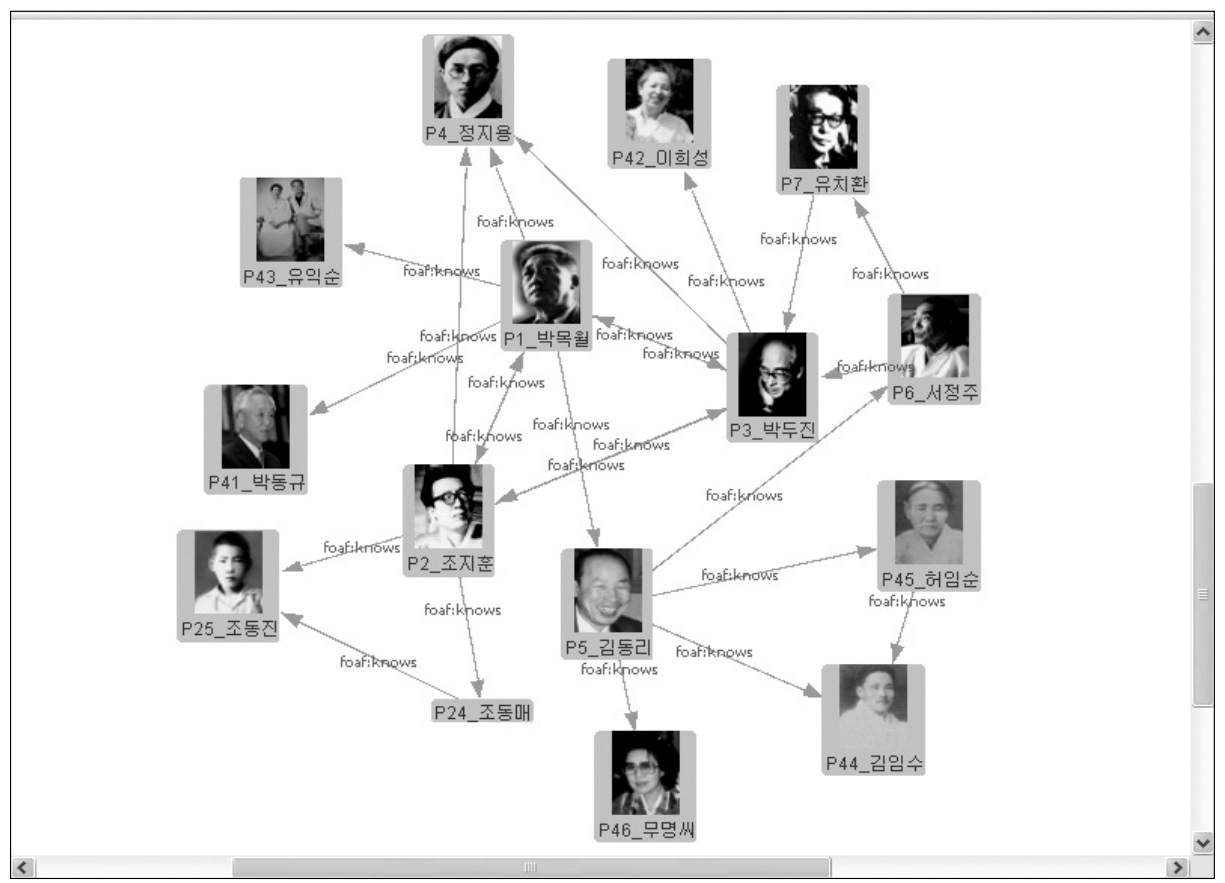

〈그림 14〉객체속성의 계층상속 관계를 이용한 추론: foaf:knows 
를 들어 인물망에서 최하위 객체속성으로 사용 된 foaf:acquaintanceOf, foaf:closeFriendOf 와 같은 RELATIONSHIP의 34종 관계어휘를 그 상위 객체속성인 foaf:knows로 질의를 하면 34종 하위객체속성으로 이뤄진 트리플들이 모 두 질의결과로 보여진다.

〈그림 14〉는 RELATIONSHIP 34종의 최하위 객체속성으로 트리플이 생성된 인물망온톨로지에 대해 그 상위 객체속성인 foaf:knows로 질의하여 foaf:acquaintanceOf, foaf:closeFriendOf와 같 이 하위객체속성으로 이뤄진 트리플들이 모두 질 의결과로 제시된 화면이다. 이와 같이 명시적으로 생성되지 않은 $\mathrm{SPO}$ 트리플을 객체속성의 계층관 계의 추이적 상속을 통해 암묵적인 관계를 질의결 과로 제시함으로써 하위수준의 추론(inference) 을 수행한 결과이다.

\section{5. 결 론}

지금까지 RDF/OWL의 객체속성을 이용한 Xburv 관계온톨로지 시스템 구축과 청록파 관 계온톨로지에 대한 $\mathrm{SPARQL}$ 질의결과를 통 해 다음과 같은 연구결과를 확인할 수 있었다. 온톨로지 기반의 관계기술목록은 동일저자의 모든 저작 및 특정저작의 상이한 판을 한 데 모 으는 전통적 목록의 '일 대 다 집중' 기능을 수 행함과 동시에 1) 특정저자와 주제적, 사회적 상호 연관 관계를 맺고 있는 다양한 영역의 관 련 저자들과 그들의 모든 저작들을 한데 모아
제시하는 '다 대 다 집중'이라는 목록의 집중기 능의 의미확장이 가능하며, 2) 전통적 목록에 서 기존 연결장치를 통한 '저록단위의 단순집 중' 기능에서, 서지세계의 개체 간 다양한 수준 과 유형의 관계를 통합적 연결장치이자 관계어 휘인 객체속성을 통해 '개체단위의 의미적 집 중'으로 보다 세분화되고 다양화된 집중기능이 가능하다. 3) 또한 온톨로지 기반의 관계기술 목록은 $\mathrm{RDF} / \mathrm{OWL}$ 객체속성의 계층상속 관계 를 이용한 관계 추론(inference)이 가능하다.

본 연구에서는 이러한 전통적 연결장치의 한 계를 극복하기 위해 온톨로지 환경에서 관계어 휘이자 통합적 연결장치로서 RDF/OWL의 객 체속성(Object Property)을 활용하였다. 또한 객체속성을 이용하여 서지세계 내 개체 간 관 계기술과 연결을 위해 burv 관계어휘를 제안하 고 이를 확장한 Xburv 관계어휘를 통해 청록 파 관계온톨로지를 구축하였다.

burv 관계어휘는 서지개체와 접근제어개체 23 종의 개체 간 관계를 검색(find), 식별(identify) 과 함께 명확화(clarify), 이해(understand)라 는 이용자 과업(user task)을 지원하는데 있어 서 개체 간의 맥락을 표현하는 중요한 역할을 할 것이다. 또한 burv 관계온톨로지는 기존 전 통적인 전거제어 업무에서 발생되었던 비효율 성과 많은 비용과 노력을 줄이고, 관계제어의 상호운용성, 통일성, 일관성, 재사용, 공유가 가 능하며 온톨로지 통합과 확장의 용이성 및 유 지관리의 편의성을 증대시킬 수 있다. 


\section{참 고 문 헌}

국립중앙도서관 도서관연구소 2007. 『목록규칙

의 국제동향 $\mathrm{III}_{\unlhd}$. 국제 서지표준 동향 워 크숍.

김태수. 2008.『목록의 이해』. 한국도서관협회: 현대정보관리학 총서, 37.

박하영. 2003.『접근제어레코드 형식구축을 위한 $\mathrm{XML}$ 스키마 개발에 관한 연구』. 연세대 학교 대학원 문헌정보학과, 석사학위논문. 신기정영. 2008. 『시맨틱 웹을 위한 RDF/OWL 입문』. 황석형, 양해술 공역. 서울: 홍릉 과학출판사.

정영하. 1997. 『패키지구조를 이용한 인명전거 시스템 구축에 관한 연구』. 연세대학교 대학원 문헌정보학과, 석사학위논문.

ALA etc. 2008. "Phasel.Glossary 10.21.08 (17 18)." American Library Association, Canadian Library Association, and The Chartered Institute of Library and Information Professionals.

ALA, CLA, CILIP. 2008. "RDA draft 2008. 10.31." [cited 2009.7.12].

〈http://www.rdaonline.org/constitue ncyreview/ $>$.

Allemang, Dean and James Hendler 저. 2009.
『온톨로지 개발을 위한 시맨틱 웹: W3C $\mathrm{RDF} \cdot \mathrm{RDFS} \cdot \mathrm{OWL}$ 기반 온톨로지 모 델링』. 김성혁, 박영택, 추영미 공역. 파 주: 사이텍미디어.

Barry Smith, Werner Ceusters etc. 2008. "Relations in biomedical ontologies." $\mathrm{Ge}^{-}$ nome Biology 2005, Volume 6, Issue 5, Article R46.

Bean and R. Green. 2001. "Relationships in the Organization of Knowledge. Dordrecht." Kluwer Academic Publishers, 19-35.

Carl Lagoze, Sandy Payette, Edwin Shin, and Chris Wilper. 2004. "Fedora: An Architecture for Complex Objects and their Relationships." Computing and Information Science, Cornell University.

IFLA Study Group on the Functional Requirements for Bibliographic Records. 2003. 서지레코드의 기능상의 요건. 김태 수 역. 서울: 국립중앙도서관.

Manola, Frank and Eric Miller. 2005. ${ }^{\circledR R D F}$ 입문서』. 김태수, 심경 공역. 서울: 한국과 학기술정보연구원. 